\title{
Anti-Synthetase Syndrome-Related Interstitial Lung Disease With Anti-PL-12 Antibodies
}

\author{
Belqis Elferjani ${ }^{1}$, Adnan Liaqat ${ }^{1}$, Mohammed Zaman ${ }^{1}$, Marvin Sexton ${ }^{2}$ \\ 1. Internal Medicine, Southeast Health Medical Center, Dothan, USA 2. Pulmonology, Dothan Pulmonary Associates, \\ Dothan, USA
}

Corresponding author: Adnan Liaqat, adnan.liaqat873@yahoo.com

\begin{abstract}
Anti-synthetase syndrome usually comprises interstitial lung disease, myositis, arthralgias, and Raynaud phenomenon. The anti-PL-12 antibody is directed against the enzyme alanyl-tRNA synthetase and has been associated with interstitial lung disease in the absence of inflammatory myositis. We report the case of a 33year-old woman with complaints of progressive dyspnea, a persistent dry cough, along with intermittent low-grade fever for a few months. A computed tomography (CT) scan of the chest showed the presence of patchy bilateral airspace opacities and infiltrates. It also showed significant mediastinal and hilar lymphadenopathy. Bronchoscopy with transbronchial biopsy was performed, and histopathology changes were consistent with connective tissue disease related to interstitial lung disease. Further workup revealed the presence of anti-PL-12 antibodies. This case illustrates a rare association of interstitial lung disease with the anti-PL-12 antibody.
\end{abstract}

Categories: Internal Medicine, Pulmonology, Rheumatology

Keywords: anti-synthetase syndrome, interstitial lung disease, anti-pl-12 antibody

\section{Introduction}

Anti-synthetase syndrome (AS) is a rare and chronic autoimmune disease with autoantibodies directed against amino-acyl transfer RNA synthetase. Its clinical features range from arthritis, myositis, Raynaud's phenomenon, mechanic's hands, to interstitial lung disease [1]. The interstitial lung disease in antisynthetase syndrome carries a poor prognosis with increased morbidity and mortality when compared with other inflammatory myopathies [2].

Aminoacyl-tRNA synthetase autoantibodies were first identified in the 1980s [3]. In the 1990s, it became well-known that these antibodies are linked to distinct clinical features, leading to the official recognition of anti-synthetase syndrome [4-5]. Anti-Jo 1 antibodies are most common (20\%), whereas anti-PL-12 antibodies (alanyl-tRNA synthetase) occur in $<3 \%$ of known cases.

Review began 01/18/2021 Review ended 01/20/2021 Published 01/27/2021

\section{๑) Copyright 2021}

Elferjani et al. This is an open access article distributed under the terms of the Creative Commons Attribution License CC-BY 4.0., which permits unrestricted use, distribution, and reproduction in any medium, provided the original author and source are credited.
Anti-synthetase syndrome usually comprises interstitial lung disease, myositis, arthralgia, and Raynaud phenomenon. The anti-PL-12 antibody is directed against the enzyme alanyl-tRNA synthetase and has been associated with interstitial lung disease in the absence of inflammatory myositis. This case illustrates a rare association of interstitial lung disease with the anti-PL-12 antibody.

\section{Case Presentation}

We report the case of a 33-year-old woman with a past medical history significant for asthma, iron deficiency anemia, and former smoking who presented with complaints of progressive dyspnea, persistent dry cough, and two recent episodes of pneumonia that was adequately treated. She further had a 10-month history of intermittent, low-grade fever associated with gradual weight loss over the same time period. She denied any hemoptysis, chills, or occupational dust exposure. She had no recent administration of medications known to cause anatomic or pathological pulmonary abnormalities.

Initial lab work included white blood cell (WBC) $12.3 \times 10^{9} / \mathrm{L}, \mathrm{Hg} 9.1 \mathrm{mg} / \mathrm{dl}$ with mean corpuscular volume (MCV) 61.5 , platelets $565 \times 10^{9} / \mathrm{L}$, creatinine $0.54 \mathrm{mg} / \mathrm{dl}$, Na $138 \mathrm{mEq} / \mathrm{L}, \mathrm{K} 4.4 \mathrm{mEq} / \mathrm{L}$, aspartate aminotransferase (AST) 12 units/L, alanine transaminase (ALT) 4 units/L. Lactate was $0.56 \mathrm{mmol} / \mathrm{L}$ and Ddimer was $219 \mathrm{ng} / \mathrm{mL}$. Urinalysis was negative for any significant findings. Partial thromboplastin time (PTT) was 29.4 seconds, prothrombin time (PT) 13.3 seconds, and international normalized ratio (INR) 1.17. The initial chest X-ray is shown in Figure 1. 


\section{Cureus}

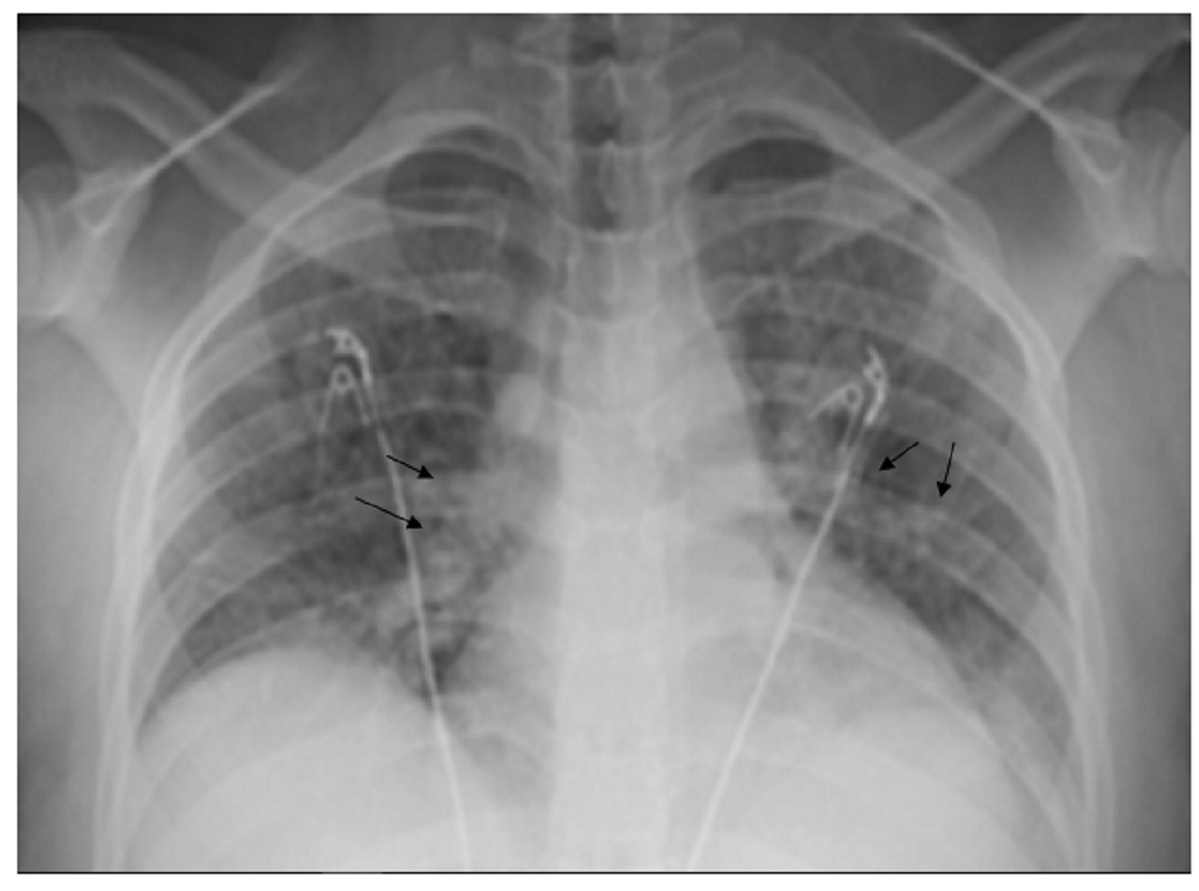

FIGURE 1: Chest X-ray showing bilateral interstitial and airspace opacities

The computed tomography (CT) scan of the chest showed the presence of bilateral interstitial opacities, ground-glass opacities, subpleural nodules, and bronchiectasis. It also showed significant mediastinal and hilar lymphadenopathy. CT images are shown in Figure 2.
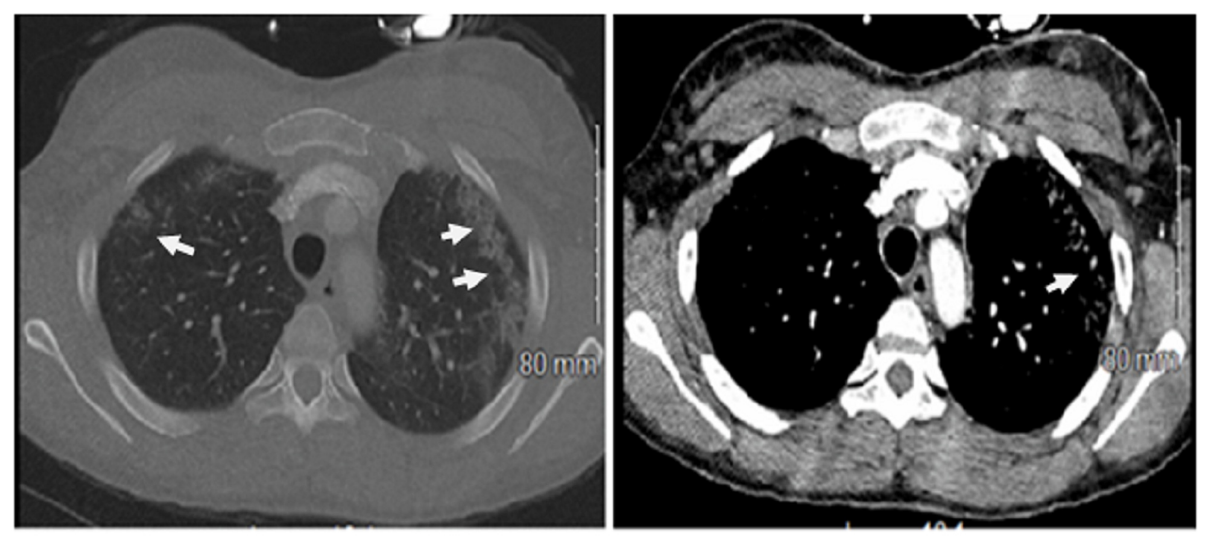

FIGURE 2: Computed tomography of the chest showing bilateral interstitial opacities, ground-glass opacities, and bronchiectasis

Both the viral respiratory infectious panel and hypersensitivity pneumonitis panel were negative. The influenza screen was negative. The hepatitis B surface antigen ( $\mathrm{HBsAg}$ ) and hepatitis B surface antibody ( $\mathrm{HBsAb}$ ) were negative. The C-3 and C-4 complement levels were within the normal range, $171 \mathrm{mg} / \mathrm{dl}$ and $42.7 \mathrm{mg} / \mathrm{dL}$, respectively. The Quantiferon TB (tuberculosis) gold test was negative. Serum aldolase was 6.9 $\mathrm{U} / \mathrm{L}$ and total creatinine kinase (CK) was $81 \mathrm{U} / \mathrm{L}$.

Bronchoscopy with bronchoalveolar lavage (BAL) and transbronchial biopsy was performed, and histopathology changes were consistent with connective tissue disease related to interstitial lung disease as shown in Figure 3. 


\section{Cureus}
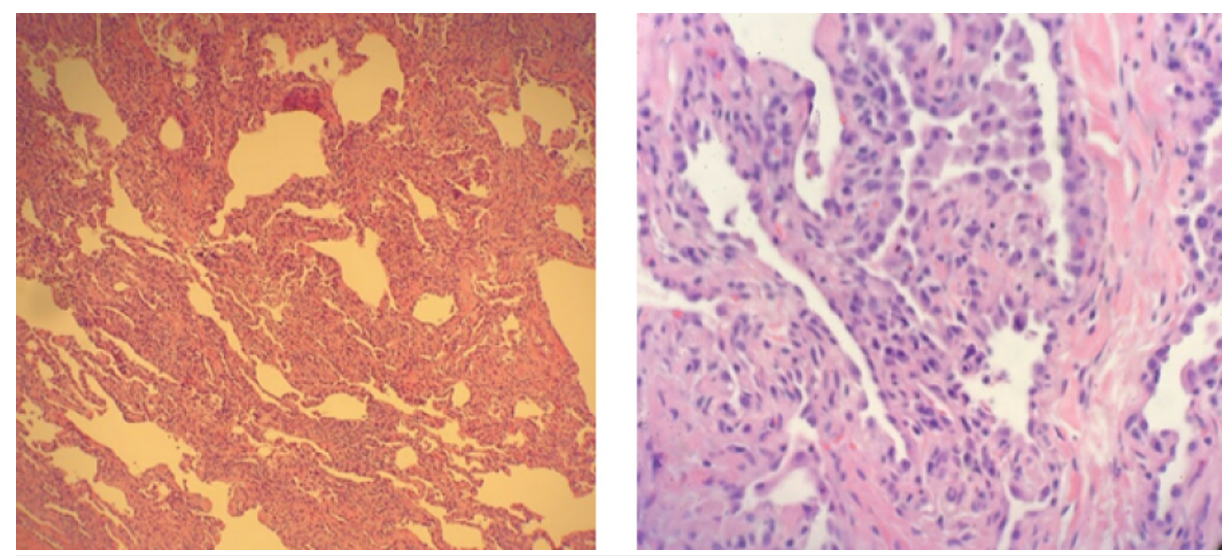

FIGURE 3: Histopathology from transbronchial biopsy sample showing a pattern of fibrosis obscuring the normal alveolar architecture consistent with chronic cellular and fibrosing interstitial pneumonia

The BAL culture was negative for any organism, including acid-fast bacilli (AFB). The serology panel for all antibodies was negative except for PL-12 autoantibodies as shown in Table 1.

\begin{tabular}{|c|c|c|c|}
\hline Serology & Results & Serology & Results \\
\hline ANA & 1:1280 & Anti-SCL-70 & Negative \\
\hline Aldolase & Negative & Anti-SM & Negative \\
\hline Anti-ds-DNA & Negative & Anti-SSA & Negative \\
\hline Anti-SSB & Negative & Anti-U1RNP & Negative \\
\hline Anti-Jo-1 & Negative & Anti-PL-7 & Negative \\
\hline Anti-EJ & Negative & Anti-PL-12 & Positive \\
\hline
\end{tabular}

\section{TABLE 1: Illustrates positivity for the anti-PL-12 antibody}

\section{Discussion}

Inflammatory myopathies include a heterogeneous group of autoimmune disorders with various clinical subgroups. AS is one of the major subgroups with anti-synthetase antibodies. AS is characterized by varying degrees of interstitial lung disease (ILD), myositis, arthropathy, fever, Raynaud's phenomenon, and mechanic's hands, and the morbidity and mortality of the disease are usually linked to pulmonary findings. Corticosteroids are the mainstay of acute therapy, although treatment often requires immunosuppressant medications such as cyclophosphamide, azathioprine, mycophenolate mofetil, cyclosporine, tacrolimus, or rituximab [6]. AS syndrome with ILD carries a grim prognosis and the presence of AS antibodies is the strongest predictor of ILD development [7].

Our patient with AS syndrome-related ILD and positive anti-PL 12 antibodies had no associated myositis. To our knowledge, the absence of myositis in AS syndrome with anti-PL 12 antibodies is relatively rare and there are only a few case reports reported so far. After a detailed review of such cases, we compiled a table of such cases (Table 2). 


\section{Cureus}

\begin{tabular}{|c|c|c|c|c|c|c|c|c|}
\hline & Author & Reference & Age/sex & Presentation & Diagnosis & Myositis & Treatment & Outcomes \\
\hline $\begin{array}{l}\text { Case } \\
1\end{array}$ & $\begin{array}{l}\text { Ghysen K. } \\
\text { et al. }\end{array}$ & [8] & $64, M$ & $\begin{array}{l}\text { Dry cough; } \\
\text { progressive dyspnea; } \\
\text { arthralgia }\end{array}$ & $\begin{array}{l}\text { ILD related to the anti- } \\
\text { synthetase syndrome }\end{array}$ & No & $\begin{array}{l}\text { Steroid and } \\
\text { azathioprine }\end{array}$ & $\begin{array}{l}\text { Good } \\
\text { response }\end{array}$ \\
\hline $\begin{array}{l}\text { Case } \\
2\end{array}$ & $\begin{array}{l}\text { Tokunaga } \\
\mathrm{K}, \mathrm{H} \text {. et al. }\end{array}$ & [9] & $65, \mathrm{~F}$ & $\begin{array}{l}\text { Fever and dry cough, } \\
\text { Dyspnea }\end{array}$ & ILD & Yes & $\begin{array}{l}\text { mPSL; CyA; IVCY; } \\
\text { with concomitant } \\
\text { RTX cycles }\end{array}$ & Improving \\
\hline $\begin{array}{l}\text { Case } \\
3\end{array}$ & $\begin{array}{l}\text { Yahaba M, } \\
\text { S. et al. }\end{array}$ & [10] & $37, \mathrm{~F}$ & $\begin{array}{l}\text { Extreme proximal } \\
\text { muscle weakness }\end{array}$ & $\begin{array}{l}\text { Necrotizing autoimmune } \\
\text { myositis in the association } \\
\text { of ILD }\end{array}$ & Yes & Steroid; IVIG & Improving \\
\hline $\begin{array}{l}\text { Case } \\
4\end{array}$ & $\begin{array}{l}\text { Satoh, } \mathrm{H} \text {. } \\
\text { et al. }\end{array}$ & [11] & $55, \mathrm{~F}$ & $\begin{array}{l}\text { Progressive dyspnea } \\
\text { and polyarthralgia }\end{array}$ & Interstitial pneumonia & No & Steroid & Improving \\
\hline
\end{tabular}

TABLE 2: Literature review of the reported cases on the anti-PL-12 antibody-associated antisynthetase syndrome with clinical presentation and management

ILD: interstitial lung disease; CyA: cyclosporine A; mPSL: methylprednisolone; IVCY: intravenous cyclophosphamide; RTX: rituximab; IVIG: intravenous immunoglobulin

Interstitial disease can be the only manifestation of the anti-synthetase syndrome in the absence of inflammatory myositis. This case highlights the significance of considering anti-synthetase antibodies in patients with interstitial lung disease with no other signs of connective tissue disease.

\section{Conclusions}

We conclude that the anti-PL-12 antibody is associated with the presence of ILD, but it differs from other antibodies associated with the anti-synthetase syndrome, like anti-jo- 1 and anti-7, due to the absence of myositis and arthritis. The anti-PL-12 antibody can be an underlying cause of idiopathic ILD. Finally, further investigation is required to understand this disease entity and to improve diagnostic and therapeutic strategies.

\section{Additional Information}

\section{Disclosures}

Human subjects: Consent was obtained or waived by all participants in this study. Conflicts of interest: In compliance with the ICMJE uniform disclosure form, all authors declare the following: Payment/services info: All authors have declared that no financial support was received from any organization for the submitted work. Financial relationships: All authors have declared that they have no financial relationships at present or within the previous three years with any organizations that might have an interest in the submitted work. Other relationships: All authors have declared that there are no other relationships or activities that could appear to have influenced the submitted work.

\section{References}

1. Connors GR, Christopher-Stine L, Oddis CV, Danoff SK: Interstitial lung disease associated with the idiopathic inflammatory myopathies. What progress has been made in the past 35 years?. Chest. 2010, 138:1464-1474. 10.1378/chest.10-0180

2. Kalluri M, Oddis CV: Pulmonary manifestations of the idiopathic inflammatory myopathies . Clin Chest Med. 2010, 31:501-512. 10.1016/j.ccm.2010.05.008

3. Mathews MB, Reichlin M, Hughes G, Bernstein R: Anti-threonyl-tRNA synthetase, a second myositis-related autoantibody. J Exp Med. 1984, 160:420-434. 10.1084/jem.160.2.420

4. Marguerie C, Bunn C, Beynon H, Bernstein R, Hughes J, So A, Walport M: Polymyositis, pulmonary fibrosis and autoantibodies to aminoacyl-tRNA synthetase enzymes. QJM. 1990, 77:1019-1038. 10.1093/qjmed/77.1.1019

5. Love LA, Leff RL, Fraser DD, Targoff IN, Dalakas M, Plotz PH, Miller FW: A new approach to the classification of idiopathic inflammatory myopathy. Myositis-specific autoantibodies define useful homogeneous patient groups. Medicine. 1991, 70:360-374. 10.1097/00005792-199111000-00002

6. Katzap E, Barilla-LaBarca ML, Marder G: Antisynthetase syndrome. Curr Rheumatol Rep. 2011, 13:175-181. 10.1007/s11926-011-0176-8

7. Váncsa A, Csípo I, Németh J, Dévényi K, Gergely L, Dankó K: Characteristics of interstitial lung disease in SS-A positive/Jo-1 positive inflammatory myopathy patients. Rheumatol Int. 2009, 29:989-994. 10.1007/s00296-009-0884-9

8. Ghysen K, Leys M: A 64-year-old woman with interstitial lung disease and positive antibodies against 


\section{Cureus}

aminoacyl-transfer RNA synthetases in the absence of myositis: presentation of an anti-PL-12 positive antisynthetase syndrome. Acta Clin Belg. 2018, 73:389-392. 10.1080/17843286.2017.1403133

9. Tokunaga K, Hagino N: Dermatomyositis with rapidly progressive interstitial lung disease treated with rituximab: a report of 3 cases in Japan. Intern Med. 2017, 1399-1403. 10.2169/internalmedicine.56.7956

10. Yahaba M, Suda A, Syoji R, Jujo T, Shinozaki T: A case of rapidly progressive interstitial pneumonia with anti-pL-12-antibodies successfully treated by pulse methylprednisolone and cyclophosphamide [Article in Japanese]. Nihon Kokyuki Gakkai Zasshi. 2008, 46:547-551.

11. Satoh S, Hirakata M, Suwa A, Mimori T, Inada S, Akizuki M: Two cases of interstitial pneumonia with antiPL-12 (alanyl tRNA synthetase) antibodies [Article in Japanese]. Ryumachi. 1996, 36:862-868. 